\title{
The Classification of some Violet-Pigmented Micrococci
}

\author{
By M. KOCUR AND T. MARTINEC \\ Department of Microbiology, Faculty of Sciences, University of J. E. Purkynĕ, \\ Brno, Czechoslovakia
}

(Received 13 April 1962)

SUMMARY

Seven strains of micrococci which produce violet pigment were studied. We recommend that the names Staphylococcus flavocyaneus Knaysi and Micrococcus polychromus Makarova should be regarded as synonyms of $M$. luteus (Shroeter) Cohn, and consider that M. violagabriellae Castellani belongs to the species Staphylococcus epidermidis. For the practical diagnosis of micrococci we recommend that those strains which form a violet pigment, which do not give acid in glucose peptone water and do not form acetylmethylcarbinol, should be identified as atypical strains of Micrococcus luteus.

\section{INTRODUCTION}

Several species of micrococci which produce violet pigment have been described but their classification is not satisfactory; Micrococcus cyaneus (Schroeter) Cohn (1872), and Staphylococcus flavocyaneus Knaysi (1942) are examples. Hucker (1928) thought that they probably belong to the species $M$. flavus and therefore they are not described in the 7th edition of Bergey's Manual (1957). Krasilnikov (1949) did not mention any species of violet-pigmented cocci in his guide. Shaw, Stitt \& Cowan (1951) considered that $\boldsymbol{S}$. flavocyaneus is identical with $\boldsymbol{S}$. afermentans. The more recently described cocci, $M$. polychromus Makarova (1949) and $M$. violagabriellae Castellani (1955) are not classified in the 7th edition of Bergey's Manual. We have studied seven strains of micrococci which produce violet pigment obtained from various collections.

\section{METHODS}

The methods used were those described previously (Kocur \& Martinec, 1959). The strains studied were strains Bs 622, 851, 853, Micrococcus flavocyaneus; strain Bs 856, M. cyaneus; strain Bs 852, Micrococcus sp. : all from C. B. van Niel (Hopkins Marine Station of Stanford University, Pacific Grove, California, U.S.A.), strain BS 247, Staphylococcus flavocyaneus Knaysi NCTC 7011 from National Collection of Type Cultures, London; strain Bs 575, M. violagabriellae from A. Castellani, Institute for Tropical Medicine, Lisbon, Portugal.

\section{RESULTS}

Morphology. All the strains showed Gram-positive cocci of diameter $1 \cdot 2-2 \mu$, occurring in clumps; cubical packets were formed only by strains 247,622 and 851 . All the strains were non-motile.

Cultural characteristics. On nutrient agar all the strains formed round slightly 
Table 1. Biochemical characteristics of violet-pigmented strains compared with those of known species of micrococci

The tests were made as described by Kocur \& Martinec (1959).

\begin{tabular}{|c|c|c|c|c|c|c|c|c|c|}
\hline \multirow[b]{2}{*}{ Test } & \multicolumn{6}{|c|}{ Strain no. } & \multirow{2}{*}{$\begin{array}{l}\text { Micro- } \\
\text { coccus } \\
\text { luteus* }\end{array}$} & \multirow{2}{*}{$\begin{array}{c}\text { Micrococcus } \\
\text { poly- } \\
\text { chromus } \\
\text { Makarova, } \\
1949\end{array}$} & \multirow{2}{*}{$\begin{array}{c}\text { Micro- } \\
\text { coccus } \\
\text { viola- } \\
\text { gabriellae, } \\
\text { strain } 575\end{array}$} \\
\hline & 247 & 622 & 851 & 852 & 853 & 856 & & & \\
\hline $\begin{array}{l}\text { Acid from } \\
\text { Glucose }\end{array}$ & - & - & - & - & - & 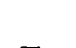 & & & \\
\hline Lactose & - & - & - & - & - & $\overline{-}$ & 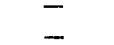 & $\begin{array}{l}- \\
-\end{array}$ & $\begin{array}{l}+ \\
+\end{array}$ \\
\hline Sucrose & - & - & - & - & - & - & - & - & $\begin{array}{l}+ \\
+\end{array}$ \\
\hline Maltose & - & - & - & - & - & - & - & - & + \\
\hline Galactose & - & - & - & - & - & - & - & 0 & + \\
\hline Fructose & - & - & - & - & - & - & - & 0 & + \\
\hline Rhamnose & - & - & - & - & - & - & - & $\mathbf{0}$ & - \\
\hline Mannose & - & - & - & - & - & - & - & o & + \\
\hline Inulin & - & - & - & - & - & - & - & 0 & - \\
\hline Xylose & - & - & - & - & - & - & - & - & - \\
\hline Arabinose & - & - & - & - & - & - & - & 0 & - \\
\hline Glycerol & - & - & - & - & - & - & - & 0 & + \\
\hline Adonitol & - & - & - & - & - & - & - & $\mathbf{0}$ & - \\
\hline Sorbitol & - & - & - & - & - & - & - & 0 & - \\
\hline Mannitol & - & - & - & - & - & - & - & o & + \\
\hline Dulcitol & - & - & - & - & - & - & - & 0 & - \\
\hline Salicin & - & - & - & - & - & - & - & o & - \\
\hline Aesculin hydrolysis & - & - & - & - & - & - & $(-)$ & $\mathbf{0}$ & - \\
\hline Starch hydrolysis & - & - & + & - & + & - & $(-)$ & $\mathbf{0}$ & - \\
\hline Sodium citrate utilized & - & - & - & - & - & - & $(-)$ & 0 & - \\
\hline Acetoin formed & - & - & - & - & - & - & - & $\mathbf{0}$ & + \\
\hline Methyl red & - & - & - & - & - & - & - & 0 & - \\
\hline Gelatin hydrolysis & + & + & + & + & + & + & $(+)$ & + & - \\
\hline Casein hydrolysis & + & + & + & + & + & - & $(+)$ & $\mathbf{0}$ & - \\
\hline Nitrate reduced to nitrite & + & + & + & + & + & + & $(-)$ & - & + \\
\hline Hydrogen sulphide & - & - & - & - & - & - & $(-)$ & $\mathbf{0}$ & - \\
\hline Indole & - & - & - & - & - & - & - & $\mathbf{0}$ & - \\
\hline Milk coagulation & - & - & - & - & - & - & $(-)$ & + & - \\
\hline Phenylalanine deaminated & - & - & - & - & - & - & - & 0 & - \\
\hline Catalase & + & + & + & + & + & + & + & + & + \\
\hline Haemolysis & - & - & - & - & - & - & - & - & - \\
\hline Coagulase & - & - & - & - & - & - & - & $\mathbf{0}$ & - \\
\hline Phosphatase & - & - & - & - & - & - & - & $\mathbf{0}$ & - \\
\hline Urease & - & + & + & + & + & - & $(-)$ & $\mathbf{0}$ & + \\
\hline Lipase & - & - & - & - & - & + & $(-)$ & $\mathbf{0}$ & + \\
\hline Yellow pigment on nutrient agar & + & + & + & + & + & - & $(+)$ & + & - \\
\hline Sensitivity to & & & & & & & & & - \\
\hline $\begin{array}{l}\text { Penicillin } 10 \text { units } / \mathrm{ml} \text {. } \\
\text { Streptomycin } 20 \mu \mathrm{g} . / \mathrm{ml} \text {. }\end{array}$ & $\begin{array}{l}+ \\
+\end{array}$ & $\begin{array}{l}+ \\
+\end{array}$ & $\begin{array}{l}+ \\
+\end{array}$ & $\begin{array}{l}+ \\
+\end{array}$ & $\begin{array}{l}+ \\
+\end{array}$ & $\begin{array}{l}+ \\
+\end{array}$ & $\begin{array}{l}(+) \\
(+)\end{array}$ & $\begin{array}{l}0 \\
0\end{array}$ & + \\
\hline Chloramphenicol $20 \mu \mathrm{g} . / \mathrm{ml}$. & + & + & + & $\begin{array}{l}+ \\
+\end{array}$ & + & $\begin{array}{l}+ \\
+\end{array}$ & $(+)$ & o & + \\
\hline Chlortetracycline $100 \mu \mathrm{g} . / \mathrm{ml}$. & + & + & + & + & + & + & $(+)$ & 0 & + \\
\hline Terramycin $50 \mu \mathrm{g} . / \mathrm{ml}$. & + & + & + & + & + & + & - & $\mathbf{0}$ & + \\
\hline Tetracycline $50 \mu \mathrm{g} . / \mathrm{ml}$. & + & + & + & + & + & + & $(+)$ & $\mathbf{0}$ & + \\
\hline Erythromycin $20 \mu \mathrm{g} . / \mathrm{ml}$. & + & + & + & + & + & + & $(+)$ & 0 & + \\
\hline Neomycin $40 \mu \mathrm{g} . / \mathrm{ml}$. & + & + & + & + & + & + & $(+)$ & 0 & + \\
\hline Tyrothricin $40 \mu \mathrm{g} / \mathrm{ml}$. & - & - & - & - & - & - & - & 0 & - \\
\hline Nystatin 20 units $/ \mathrm{ml}$. & + & + & + & + & + & + & $(+)$ & $\mathbf{0}$ & - \\
\hline Bacitracin 5 units/ml. & + & + & + & + & + & + & $(+)$ & $\mathbf{0}$ & - \\
\hline Lysozyme & + & + & + & + & + & + & $(+)$ & $\mathbf{0}$ & - \\
\hline
\end{tabular}

Explanations: $+=$ positive $(+)=$ most strains positive; $-=$ negative $(-)=$ most strains negative 0 = data not given; * = data from Kocur \& Martinec (1962). 
convex, smooth colonies with an entire, or slightly modulate margin. In five strains the colour of the colonies was yellow, but they also formed another pigment which diffused into the medium and gave it a light brown colour. Strain 856 formed violet-black colonies. Strain 575 (Micrococcus violagabriellae) did not produce pigment on any of the media used. The strains formed colonies which were similar in form and colour to the colonies grown on nutrient agar, except that they produced a violet pigment which diffused into the medium on glucose yeast agar (Rosypal, Kocur \& Hodák, 1963). Strain 856 formed rough dark-violet colonies on this medium but the pigment diffused only slightly into the medium. All the strains except $M$. violagabriellae produced pigment on potato and on most of the usual diagnostic media (starch agar, fat agar, etc). All the strains formed a slight turbidity and sediment in nutrient broth.

Biochemical characteristics. These are shown in Table 1.

\section{DISCUSSION}

With the exception of Micrococcus violagabriellae Bs 575 all the strains had similar biochemical properties (Table 1). A detailed comparison showed that all the strains other than Bs $\mathbf{5 7 5}$ could be classified as the species $\boldsymbol{M}$. luteus. We came to this conclusion by comparing the present results with data from 149 strains of yellow-pigmented cocci and with the characteristics of $M$. luteus (Kocur \& Martinec, 1962). The only constant difference between these strains and $\boldsymbol{M}$. luteus was in pigmentation. However, on nutrient agar these strains formed yellow or greenish yellow colonies similar in colour to those of $\boldsymbol{M}$. luteus. Only when cultivated on glucose yeast agar did these strains produce a violet diffusible pigment not observed on other diagnostic media (e.g. gelatin, starch agar, Simmons's citrate medium, blood agar, etc.).

The production of this violet diffusible pigment is not only dependent on the medium, since Rosypal et al. (1963) have shown that Staphylococcus flavocyaneus and other strains of violet cocci can lose the ability to produce it, but no change in the production of the yellow pigment was noticed on nutrient agar. For these reasons we do not consider the production of a violet pigment is a suitable criterion for the differentiation of micrococci into species. Strain BS 856 differed somewhat from the others; we think that it is an atypical strain of M. luteus.

Another species, which produced a violet pigment, the validity of which is questionable, is Micrococcus polychromus described by Makarova (1949). We have not studied a strain of this species, but the description of the biochemical properties of the pigment is in agreement with that of strains which we studied. We think it unlikely that it forms a new species and that it is probably a strain of $M$. luteus.

On the basis of these results we recommend that those micrococci which produce a violet pigment and which do not acidify glucose peptone water nor form acetylmethylcarbinol should be classified as Micrococcus luteus.

Micrococcus violagabriellae, strain Bs 575, differed substantially from the other strains we studied. According to the original description this species is supposed to produce a violet pigment on glucose agar and on potato. The strain which we received directly from Dr A. Castellani, however, and also a strain from the American Type Culture Collection (ATCC 12328) did not produce pigment on either of these 
media nor on any other diagnostic media. They may have lost their pigmentforming ability during maintenance. In contrast to Castellani's data the strain we studied formed acetylmethylcarbinol, gave acid in lactose peptone water and in mannitol peptone water, and did not liquefy gelatin. These apparent differences may have been due to the use of different methods. M. violagabriellae is apparently not a species of the genus Micrococcus, but appears to belong to the species Staphylococcus epidermidis (Winslow \& Winslow, 1908) Evans. Similar conclusions were drawn by Sneath (1960).

We wish to thank Mrs J. Benešová for technical assistance.

\section{REFERENCES}

Bergey's Manual of Determinative Bacteriology (1948). 6th ed. Ed. by R. S. Breed, E. G. D. Murray and A. P. Hitchens. Baltimore: Williams and Wilkins.

Bergey's Manual of Determinative Bacteriology (1957). 7th ed. Ed. by R. S. Breed, E. G. D. Murray and N. R. Smith. Baltimore: Williams and Wilkins.

Castellani, A. (1955). Note préliminaire sur un nouveau microcoque isolé d'une dermatite axillaire superficielle tropicale. Ann. Inst. Pasteur, 89, 475.

CoHn, F. (1872). Untersuchungen über Bakterien. I. Beitr. Biol. Pfl. 1, Heft. 2, 127.

Hucker, G. J. (1928). Studies of the Coccaceae. IX. Further studies on the classification of the micrococci. Tech. Bull. N.Y. State Agric. Exp. Sta. No. 135.

KNAYSI, G. (1942). The demonstration of a nucleus in the cell of Staphylococcus. J. Bact. 43,365 .

Kocur, M. \& Martinec, T. (1959). Contribution to the taxonomic studies of Sarcina lutea Schroeter and Sarcina flava de Bary. Int. Bull. Bact. Nom. 9, 123.

Kocur, M. \& Martinec, 'T. (1962). The taxonomic study of the genus Micrococcus (in the Press).

Krasilnikov, N. A. (1949). Opredélitèl baktèrij $i$ aktinomicetov. Moscow: U.S.S.R. Acad. Sci.

Makarova, M. M. (1949). O novom pigmentovom kokke. Mikrobiologia, Moscoro, 18, 161.

Rosypal, S., Kocur, M. \& Hō̌ÁK, K. (1963). A study of violet-pigmented micrococci. Yellow-pigmented mutants of Staphylo-coccus flavocyaneus. J. gen. Microbiol. 32, 189.

Shaw, C., StitT, J. M. \& Cowan, S. T. (1951). Staphylococci and their classification. J. gen. Microbiol. 5, 1010.

SNEATH, P. H. A. (1960). A study of the bacterial genus Chromobacterium. Iowa St. J. Sci. 34, 243.

Winslow, C. E. A. \& Winslow, A. R. (1908). The Systematic Relationship of the Coccaceae. New York: J. Wiley and Sons. 